\title{
Mastitis in mare: case report
}

\author{
M.SH. Rhaymah ${ }^{1}$, Q.T. Al-Obaidi ${ }^{1}$, M.A. Hamad ${ }^{2}$ and M.A. Altalby ${ }^{1}$ \\ ${ }^{1}$ Department of Internal and Preventive Medicine, ${ }^{2}$ Department of Microbiology, \\ College of Veterinary Medicine, University of Mosul, Mosul, Iraq
}

(Received November 6, 2017; Accepted January 18, 2018)

\begin{abstract}
Mastitis is rare in mares compared with cattle, a mare suffered from mastitis was referred to the Veterinary Teaching Hospital, College of Veterinary Medicine, University of Mosul for examination with a history of abortion before two months and gradually loss of body weight. Clinical examination revealed, a swollen left mammary gland, painful to palpate, there was mild degree of edema in the tissue surrounding the gland, fluid with clot expressed from the gland, body temperature was $37.4^{\circ} \mathrm{C}$ and heart rate was $40 /$ minute. Fluid (mammary secretions), milk samples were collected under sterile condition and submitted to the laboratory for bacterial culture and identification test. The results of the culture and biochemical tests showed that the Staphylococcus spp was the etiological agent. This case was treated with systemic and local antibiotic therapy (Penicillin preparation).
\end{abstract}

Keywords: Mare, Mastitis

Available online at http://www.vetmedmosul.org/ijvs

$$
\begin{aligned}
& \text { التهاب الضرع في فرس: تقرير حالة } \\
& \text { ماجد شيال رحيمة'، قيس طالب العبيدي'، عحمد علي حمد و عحم عبد المحسن الطالبي' } \\
& \text { فرع الطب الباطني و الوقائي، فرع الاحياء المجهرية، كلية الطب البيطري، جامعة الموصل، الموصل، العراق }
\end{aligned}
$$

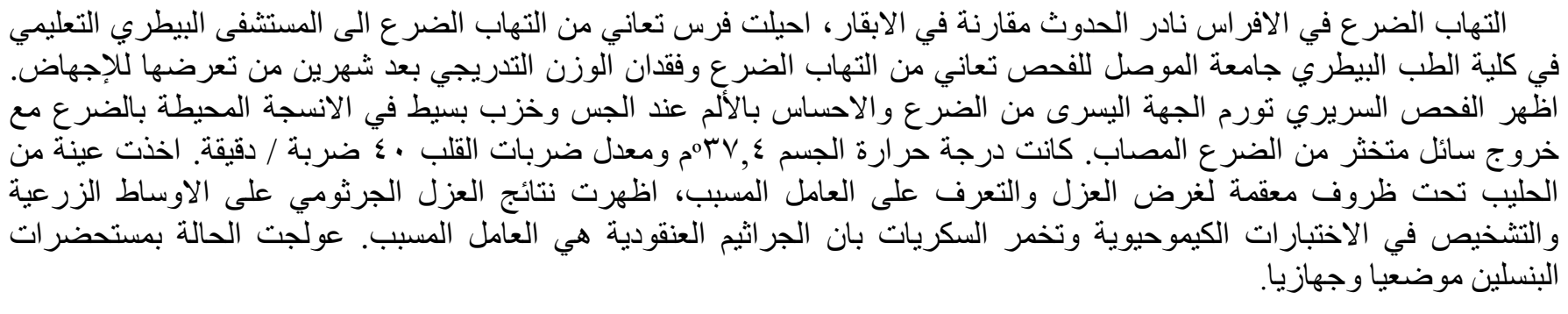

\section{Introduction}

Mastitis (Inflammation of the mammary gland) is much more common in dairy cows than mare (1-4), but lactating mares are still at risk for this painful condition, it painful for the mare and dangerous for her foal as well as, leading to malnutrition due to let her foal nurse. If not get sufficient treatment right away, abscesses or induration of the gland may occur. Most often, this disorder affects mares within one or two months of giving birth but it can affect any mare of any age (2). The majority of equine cases occur within 1 to 2 months after weaned hear foal (5). The percentage of mastitis in breeding mares was about $5 \%$, in problem stocks about $10 \%$. Mastitis mostly occurred in the phase of udder involution, but lactating and juvenile mares as well as suckling foals were also affected. About $70 \%$ of the affected mares showed abnormal secretion deviating from 
the normal appearance (6). Mastitis in mare has been firstly reported in Al-Ameria, Baghdad, Iraq (7).

The common predisposing factors of mastitis in a mare was, udder injuries (Insect bite, kick from horse), contamination of the udder from dirty bedding, inherited susceptibility to infection and abnormalities high estrogen levels due to tumor on the pituitary gland or due to legume hay (5).

The etiology of mastitis in mare was Streptococcus spp. aerobic bacteria were cultured from 71 percent of samples, $S$. zooepidemicus was the most common isolate (37 per cent). Gram-negative species accounted for 42 percent $(2,3)$, Coccidioides immitis (8). The results of the culture and biochemical tests showed that the $S$. zooepidemicus is the etiological agent of mastitis in Arabian mare suffered from mastitis was referred to Ahvaz Veterinary Clinic (9). In about $70 \%$ of secretions from mares with mastitis a pathogenic content of microorganisms - mostly S. equi ssp. zooepidemicus - was found, while $50 \%$ of secretions from mares without mastitis yielded pathogenic germs (6), in addition, a culture of the fluid expressed from the affected mammary gland will usually reveal the cause. The disease can be caused by fungi (8) and nematodes (10).

The probability for antimicrobial susceptibility of bacterial isolates from mares with mastitis indicated that a trimethoprim-sulphonamide combination would be active against more than 75 percent of isolates while penicillin would be active against less than 60 per cent. Systemic antibiotics, frequent milking, hot packs and/or hydrotherapy and, if possible, infusion of an intra mammary antibiotic preparation is recommended for treatment of equine mastitis (2).

\section{Clinical case}

A twelve - year old, thorough breed mare suffered from mastitis was referred to Veterinary Teaching Hospital, College of Veterinary Medicine, University of Mosul for examination with a history of abortion before two months and gradually loss of body weight, clinical examination revealed, a swollen left mammary gland, painful to palpate. There was mild degree of edema in the tissue surrounding the gland (Fig. 1- A), fluid with clot expressed from the gland (Fig. 1-B), body temperature was $37.4{ }^{\circ} \mathrm{C}$, heart rate was $40 /$ minute. Fluid (mammary secretions) samples was collected under sterile condition and submitted to department of microbiology, College of Veterinary Medicine for bacterial culture (isolation and identification). Samples was inoculated onto sheep blood agar, Milk agar, Mannitol salt agar and Brain heart infusion broth plates and incubated at $37{ }^{\circ} \mathrm{C}$ for 24 hours and then made bacterial identification by using biochemical tests (fermentation, substrate utilization).
The affected mare was received penicillin preparations intra mammary infusion for five days as well as systemic injection (Pen \& Strep, Norbrook, England).

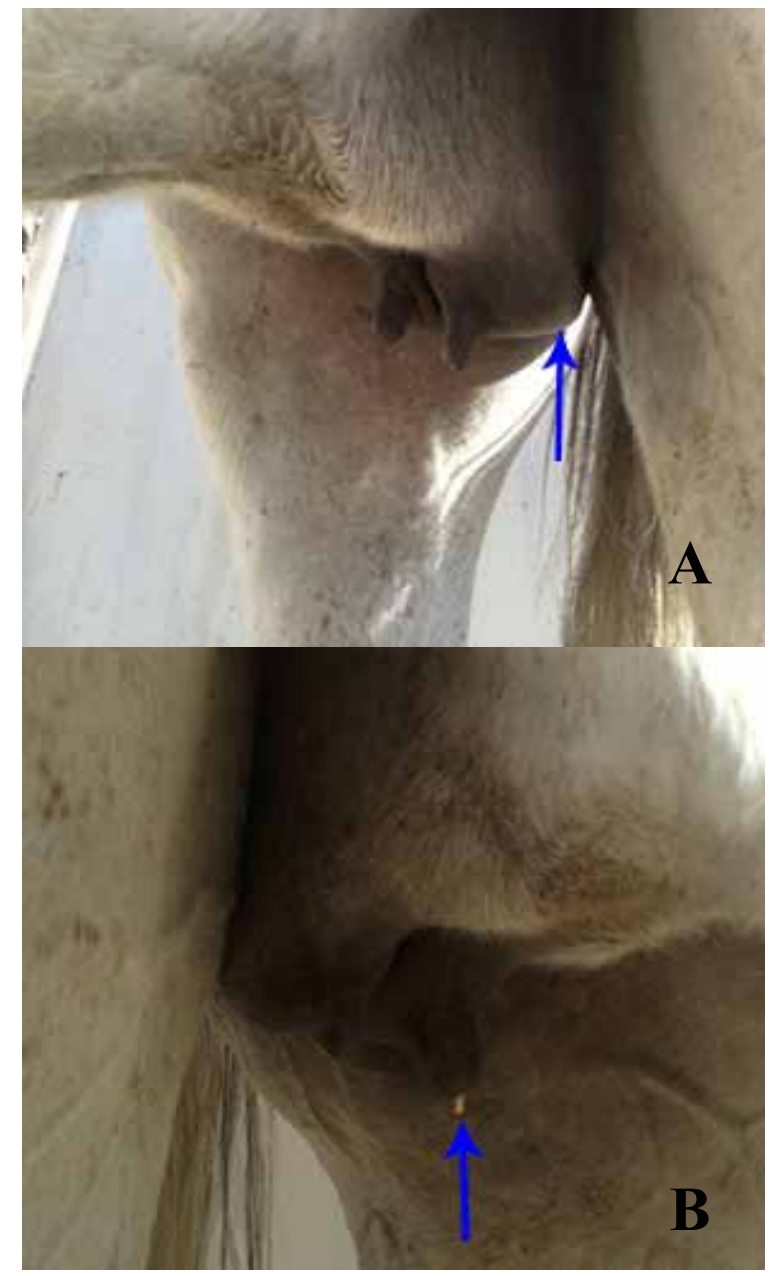

Figure 1: Clinical signs of mastitis in mare. A: Edema and swelling of affected quarter (blue raw). B: Discharge from affected teat (blue raw).

\section{Results and discussion}

Mastitis were diagnosed in a twelve - year old, had a history of abortion before two months, Mastitis (infection) and inflammation of mammary gland of the mares is rarely occur in mares compared with dairy cattle $(1,2,11)$, it may occur at any time (1), it is more frequently encountered during lactation (2) and any age or reproductive status, the majority of equine cases occur within one to two months after a mare has weaned her foal (2), while (11) reported that, mastitis in the mare most common at weaning, or during lactation. The percentage of mastitis in breeding mares was about $5 \%$, in problem stocks about $10 \%$. 
Mastitis mostly occurred in the phase of udder involution, but lactating and juvenile mares as well as suckling foals were also affected. About $70 \%$ of the affected mares showed abnormal secretion deviating from the normal appearance (6).

The clinical signs were included, gradually loss of body weight, a swollen left mammary gland before, painful to palpate, there was mild degree of edema in the tissue surrounding the gland, fluid with clot expressed from the gland, body temperature was $\left(37.4^{\circ} \mathrm{C}\right)$, heart rate was $(40 /$ minute). Researchers was recorded the same clinical signs of mastitis in the mare, (2) encountered that the risk factors of mastitis in the mare was udder injuries, insect bites, dirty bedding material and estrogen levels can affect the prevalence of mastitis (Excess estrogen enlarges the mammary glands and produces milk when no there is no viable pregnancy). The clinical signs were painful and swollen of the udder, high body temperature, depression, walking stiff standing with legs apart, may kick foal away when trying to nurse and milk consistency changed. Accumulation of edema or tissue fluid on the abdomen in front of the mammary gland (2).

Diagnosis of mastitis in mare depending on cytological evaluation of milk samples for present of large quantities of neutrophils in $72 \%$ and bacteria in $32 \%$ in milk samples from udder infection in mare (2) Cell numbers exceeding $100,000 / \mathrm{ml}$ during lactation and $400,000 / \mathrm{ml}$ during involution are regarded as pathological (6). The somatic cell counts (SCC) was performed in individual samples of each teat and showed a number higher than 500,000 cells $/ \mathrm{ml}$ of milk in only $9.3 \%$ of the 73 samples examined (12).

Culture of fluid revealed a gram positive cocci arrangement with typical cluster of Staphylococcus, It was positive for coagulase test, mannitol fermented, not produce pigmentation on milk agar medium. (2) recorded aerobic bacteria were cultured from 71 per cent of samples. Streptococcus zooepidemicus was the most common isolate (37 per cent). Gram-negative species accounted for 42 per cent, while (2) mentioned, there may be many types of bacteria and fungi that cause the infection, the most common are: Aspergillus spp. Coccidioides immitis Gram negative bacteria $S$. agalactiae, $S$. equi, $S$. equisimilis, $S$. viridans and $S$. zooepidemicus causes of Mastitis in mares. The results of the culture and biochemical tests showed that the $S$. zooepidemicus is the etiologocal agent (9). While, (6) was recorded, in about $70 \%$ of secretions from mares with mastitis a pathogenic content of microorganisms - mostly $S$. equi ssp. zooepidemicus - was found, while $50 \%$ of secretions from mares without mastitis yielded pathogenic germs. About the study cared out in Brazil (12) the microbiological culture was carried out in $10 \%$ agar bovine serum and in agar MacConkey. Both exams revealed the presence of Staphylococcus spp. and Streptococcus spp., predominantly. Kocabiyik et al. (13) were described of a neonatal septicemia due to $S$. equi subsp. Zooepidemicus and associated mastitis in mare.

The affected mare was received penicillin intra mammary infusion for five days as well as systemic injection. Determination of the probability for antimicrobial susceptibility of bacterial isolates from mares with mastitis indicated that a trimethoprim-sulphonamide combination would be active against more than 75 per cent of isolates while penicillin would be active against less than 60 per cent. Systemic antibiotics, frequent milking, hot packs and/or hydrotherapy and, if possible, infusion of an intra mammary antibiotic preparation is recommended for treatment of equine mastitis (2).

In conclusion, in this report, we describe a case of mastitis in aborted through breed mare caused by Staphylococcus spp. and treated with penicillin (Intra mammary and systematically).

\section{References}

1. Jackson PG. Equine mastitis comparative lessons. Equine Vet J. 1986;18: 88-89.

2. McCue PM. WILSON WD. Equine mastitis - a review of 28 cases NCBI. Equine Vet J. 1989;21(5):351-353.

3. Perkins N.R. and Threlfall, W. R. Mastitis in the mare. Eqine Vet Edue. 1993;5(3):192-195.

4. Reese GL. and Lock TF. Streptococcal mastitis in the mare. J Amer Vet Med. Assoc. 1978; 173:83-84.

5. Gee EK. McCue PM. Mastitis. In Mckinno AOM.; Squires E.L.Vaala W.E. and Varner D. D. Equine Reproductive Procedures; 2nd ed. Wiley - Blackwell July. 2011;pp:287.

6. Böhm KH, Klug E. Jacobs BJ. Mastitis in the mare - A long-term study on the incidence, clinical symptoms, diagnostics, microbiology, therapy and economic importance, as well as recommendations for veterinary practice. Der Praktische Tierarzt. 2009;90(9):842-849

7. Al Graibawi MAA, Sharma VK, Ali SI. Mastitis in a mare. Case report. Vet Record. 1984;15:383.

8. Walker RL, Johnson B J, Jones K L, Pappagians D, Carlson GP. Coccididioides immitis mastitis in mare. $\mathrm{J}$ Vet Diagn Invest. 1993;5:446-448.

9. Mohammadi GHA, Mouri Bakhtiari N, Baratif F, Gouraninezhad S. Mastitis in mare; a case report. Scien Res Iranian Vet J. 2008;4(3):123-126.

10. Greiner E G, Mags MB, Smart G C Jr, Weisbrode SE. Verminous mastitis in a mare caused by a free living nematode. J Parasitol. 1991;77:320-322.

11. Morresey P R. Agalactia, dysgalactia, and Nutrition of postpartum mare. AAPE Proceedings. 1999;581(212):370-374.

12. Prestesi NCR, Langoni H, Cordeiro L.AV. Study of the milk in healthy mares or mares with subclinics mastitis using Whiteside test, microbiological culture and somatic cell count. Braz J Vet Res Anim Sci. 1999;36:3.

13. Kocabiyik AL, Buyukangaz E, Akkoc A, Ozakin C, Cangul I T. Disseminated Streptococcus equi subsp. Zooepidemicus infection in a foal and associated mastitis in a mare. Turk J Vet Anim Sci. 2008;32(6):487-490. 